\title{
BUSY BOOK MEDIA BELAJAR YANG MENARIK DAN EDUKATIF UNTUK ANAK USIA DINI
}

\author{
Arianingsih \\ Universitas Negeri Yogyakarta \\ email: arianingsih@uny.ac.id
}

\begin{abstract}
Abstrak
Penelitian ini bertujuan untuk mengetahui dan mendeskripsikan bentuk busy book dan nilai edukasi yang dikembangkan dalam busy book untuk permainan dan pembelajaran anak usia dini. Penelitian ini menggunakan metode kualitatif untuk mendeskripsikan dan menganalisis, fenonmena, peristiwa, aktivitas, sikap, persepsi, pemikiran orang secara individual maupun kelompok dalam pembelajaran anak usia dini dengan media busy book. Analisis data deskriptif menyajikan bentuk, warna, dan nilai edukasi yang dapat dibelajarkan untuk anak usia dini. Hasil penelitian menunjukan bahwa bentuk visual busy book memiliki keunikan pada tema, bentuk, warna, struktur yang dapat dilepas, ditempel, dibuka, ditutup layaknya seperti buku album. Permainan busy book untuk mengembangkan pemahaman logika anak tentang bentuk, warna, keseimbangan, dan komposisi yang harmonis dan tepat. Sebagai media pembelajaran baru busy book layak, menarik, dan dan tepat untuk permaian dan pembelajaran karakter bagi anak. Ekspresi anak dalam bermain dan belajar dengan busy book menunjukan keasyikan, keseriusan, dan kesenangan tersendiri yang perlu ditafsir dan dimaknai sebagai sebuah proses edukasi yang baik bagi anak. Materi permainan busy book sebagai media pembelajaran estetis dan etis untuk mengetahui perkembangan ekspresi estetik anak.
\end{abstract}

Kata kunci: nilai edukasi, busy book, anak usia dini

\section{ENGAGING AND EDUCATIONAL LEARNING BUSY BOOK FOR EARLY CHILDREN}

\begin{abstract}
This study aimed to identify and describe the form of busy books and the educational value developed in busy books for early childhood games and learning. This study used qualitative methods to describe and analyze phenomena, events, activities, attitudes, perceptions, thoughts of people individually and in groups in early childhood learning with busy book media. The descriptive data analysis presented shapes, colors, and educational values taught to early childhood. The results show that the visual form of busy books is unique in terms of theme, shape, color, structure, which can be removed, pasted, opened, and closed like an album book. Busy book games aim to develop children's logical understanding of harmonious and appropriate form, color, balance, and composition. As a new learning medium, a busy book is feasible, engaging, and appropriate for games and character learning for children. Children's expressions in playing and learning with busy books show their preoccupation, seriousness, and pleasure that needs to be interpreted and interpreted as an excellent educational process for children. Busy book game material as an aesthetic and ethical learning media also aims to determine children's aesthetic expression development.
\end{abstract}

Keywords: educational value, busy book, early childhood 


\section{PENDAHULUAN}

Golden Age atau masa keemasan pada anak merupakan masa yang sangat penting bagi pertumbuhan dan perkembangannya, masa ini berlangsung ketika anak memasuki usia kanak-kanak. Setiap anak terlahir dengan potensi yang berbeda-beda, memiliki kelebihan, bakat, dan minat sendiri. Anak usia dini sedang dalam tahap pertumbuhan dan perkembangan yang paling pesat, baik fisik maupun mental. Pada masa inilah kesempatan baik untuk membina kreativitas dan wawasan estetik anak agar dapat berkembang kreativitasnya dengan baik. Seorang anak akan kehilangan pengalaman estetik apabila tidak mendapat perhatian dan bimbingan dalam proses berkesenian dengan baik pada saat kanak kanak, sehingga anak tersebut akan kehilangan peluang untuk menjadi anak yang berkualitas dan memiliki kreativitas tinggi (Suyanto, 2002, p. 5)

Fenomena sekarang banyak anak dikondisikan oleh orang tuanya tidak boleh bermain ke luar rumah dipaksa harus les berbagai bidang, disediakan permainan artifisial melalui teknologi, dan kesibukan lain agar tidak bermain ke luar rumah. Sebagai akibatnya anak menjadi egois kurang peka terhadap lingkungan sosial dan kulturalnya. Dalam bidang seni anak kerap kali dipaksa harus memerankan seni layaknya orang dewasa seperti melukis dengan tema, pola, dan gaya yang sudah ditentukan menurut pikiran dan imajinasi orang dewasa, seperti kebanyakan yang terjadi dalam dunia pembelajaran seni di sekolah, di sanggar, maupun pada kegiatan lomba. Sebagai akibat dari semua fenomena itu muncul pola seni anak dengan keteknikan, tema, dan gaya yang sama untuk memenuhi permintaan guru, orang tua, dan sponsor. Anak berkarya seni bukan murni ekspresi jiwa anak sesuai perkembangannya melainkan memerankan dan mengekspresikan keinginan orang lain.

Setiap anak dari berbagai latar budaya dan lingkungan memiliki kemampuan untuk melakukan ekspresi dengan berbagai cara seperti meremas, membentuk, corat-coret atau gores-menggores baik pada pada tembok, selembar kertas, atau di hamparan tanah dan pasir sekalipun. Coretan anak adalah belajar. Coretan anak merupakan ekspresi diri dengan simbol-simbol visual untuk diekspresikan dan dikomunikasikan kepada orang lain. Coretan anak yang pada awalnya tidak beraturan, tidak membentuk, namun dengan bertambahnya usia, kemampuan, pengalaman, dan dukungan dari lingkungan, kemampuan untuk menghasilkan goresan menjadi simbol-simbol visual mulai terarah, berbentuk, dan bermakna. Bagaimana anakanak nantinya jika dikenalkan bermain dan berkarya dengan program busy book?

Banyak pula anak membuat karya seperti menggambar, membuat mobilmobilan, kertas lipat, menggambar melalui program youtube. Jika penggunaan smartphone untuk membuat karya seperti ini berdampak positif. Kebanyakan anak sekarang bermain smartphone hanya untuk bermain game dan chating dengan temannya. Pada kesempatan kali ini, research group akan mengangkat nilai-nilai edukasi pada permainan seni rupa yang dikemas dalam program busy book. Model bermain dan berkarya seni melalui program busy book ini, anak anak dilatih berkarya seni menggunakan bahan kain planel, kertas berwarna untuk didesain, dipola, dipotong, dibentuk, dan ditempelkan. Permainan ini mengembangkan banyak dimensi motorik halus anak seperti kreativitas, imajinasi, ketekunan, ketelitian dan sebagainya sebagai wahana pembentukan pendidikan apresiasi dan kreasi. Pentingnya pembelajaran dan permainan busy book ini diangkat dalam penelitian kelompok adalah karena memiliki nilai-nilai edukasi estetik untuk pengembangan apresiasi dan kreasi anak.

Dalam perspektif pendidikan, seni dipandang sebagai salah satu alat atau media untuk mendidk anak. Pembelajaran melalui 
seni memberikan keseimbangan antara intelektualitas dengan sensibilitas, rasionalitas dengan irasionalitas, dan akal pikiran dengan kepekaan emosi, agar manusia memanusia. Bahkan dalam batas-batas tertentu menjadi sarana untuk mempertajam moral dan watak. Ekspresi anak dalam bermain dan belajar dengan busy book menunjukan keasyikan, keseriusan, dan kesenangan tersendiri yang perlu ditafsir dan dimaknai sebagai sebuah proses edukasi yang baik bagi anak. Berangkat dari latar belakang permasalahan itu, ekspresi seni anak adalah ekspresi pengalaman, ekspresi yang bermakna, ekspresi estetik dengan menggunakan kualitas media ekspresi yang digunakan. Bagaimana busy book dapat meningkatkan motorik halus anak? Ekspresi seni anak memiliki ciri khusus layak untuk diteliti, ditafsirkan, dan dimaknai secara benar dalam sebuah penelitian tentang nilai-nilai edukasi melalui materi permainan busy book untuk mengetahui perkembangan ekspresi estetik anak, pembelajaran seni untuk anak, makna dan nilai estetis karya seni anak dengan adanya pengaruh lingkungan seni dan budaya di Yogyakarta yang kompleks.

\section{METODE}

Untuk mendapatkan pemahaman yang mendalam tentang nilai edukasi dalam busy book, peneliti menggunakan pendekatan deskriptif kualitatif. Metodologi penelitian kualitatif adalah prosedur penelitian yang menghasilkan data kualitatif berupa ungkapan atau catatan yang terobservasi yang menggambarkan keadaan individu secara utuh (Bogdan \& Taylor, 1993, p. 30). Penelitian kualitatif berusaha memahami orang lain dari keadaan mereka sendiri dan dari bagaimana mereka memandang dunia ini. Penelitian kualitatif adalah suatu penelitian untuk mendeskripsikan dan menganalisis, fenonmena, peristiwa, aktivitas sosial, sikap kepercayaan, persepsi, pemikiran orang secara individual maupun kelompok (Sukmadinata, 2005, p. 60).
Penelitian ini diarahkan pada setting dan perilaku pembimbing dan anak sebagai subjek penelitian secara menyeluruh. Peneliti dapat mengamati, mengumpulkan, dan mencatat data yang berhubungan dengan proses pembelajaran motorik halus anak melalui busy book. Penelitian ini didasarkan pada empat dimensi yaitu: pelaku yaitu anak, aktivitas anak dalam belajar, tempat belajar sebagai aktivitas, dan waktu terjadinya proses berkarya.

Informan penelitian ini adalah pembuat busy book, Ibu Tity Sari Handayani, orang tua, guru, dan anak sebagai informan kunci. Penentuan informan secara keseluruhan berdasarkan kelompok anak usia dini, wawancara dengan guru, orang tua, pengelola sanggar, dan anak. Alasan memilih informan tersebut adalah semua anak mendapat pelajaran/bimbingan/kegiatan seni rupa, guru dan orang tua yang membimbing memiliki pengalaman banyak dalam mendampingi anak berkarya, dan anak yang dipilih sebagai informan dan hasil karyanya dengan seleksi klarifikatif berdasarkan keunikan hasil karya, kelompok berprestasi.

Dalam penelitian ini menggunakan teknik pengumpulan data observasi, wawancara, dan dokumentasi. Observasi yang digunakan observasi partisipan. Pengamatan terfokus untuk memperoleh gambaran proses berkarya dan hasil karyanya. Metode wawancara digunakan untuk mendapatkan informasi yang mendetail dari informan dilakukan secara terbuka ditujukan kepada para pelaku guru, pengelola sanggar, dan anak. Metode dokumentasi digunakan untuk mengumpulkan data busy book yang akan dipelajari anak.

Data hasil penelitian perlu diuji keabsahannya. Untuk menguji kebenaran atau keabsahan data dilakukan trianggulasi dengan membandingkan data hasil pengamatan dengan hasil wawancara dan dukumentasi, pengamatan mendalam, dan perpanjangan keikutsertaan (Moleong, 1999, p. 178) 
Teknik analisis data menggunakan induktif dengan dua cara yaitu analisis data selama proses pengumpulan data dan analisis data setelah semua data terkumpul. Data yang diperoleh deskripsi kata-kata tentang proses pembelajaran seni lukis anak dan data visual hasil karya lukis anak. Analisis data dalam penelitian ini ada beberapa langkah. Pertama, setelah data terkumpul melalui observasi, wawancara, dan dukumentasi dilanjutkan reduksi data. Reduksi data adalah sebagai proses pemilihan, pemusatan data, pengabstrakan, dan transformasi data kasar yang muncul dari catatan lapangan dilanjutnya menentukan kesimpulan. Kedua, penyajian data sebagai suatu kumpulan informasi tersusun yang memberikan kemungkinan adanya penarikan kesimpulan dan pengambilan tindakan dari data yang sudah direduksi. Penyajian data berbentuk deskripsi kata-kata berbasis data. Ketiga, menarik kesimpulan dan temuan hasil penelitian ini.

\section{HASIL DAN PEMBAHASAN}

Mengenalkan estetika kepada anak melalui bermain bentuk-bentuk, warna, dan tema melalui media pembelajaran busy book sangat penting. Media ini dirancang untuk anak usia dini cenderung memiliki bentuk yang menarik serta warna-warna yang kontras. Contoh permainan bentuk dan warna pada busy book disajikan pada Gambar 1. Hal tersebut dimaksudkan untuk menarik perhatian anak sehingga menimbulkan rasa ingin tahu. Pembuatan media pembalajaran yang menarik untuk anak dikemas dalam bentuk yang cenderung berkaitan dengan tema diri sendiri, alam atau lingkungan sekitar, budaya dan kesenian, dunia binatang, pengalaman, alat komunikasi, tranportasi, sebagai wahana untuk membangun imajinasi anak dalam bermain dan belajar. Gambar 2 menyajikan pengenalan terhadap berbagai jenis binatang, makanan, dan tempat tinggalnya.
Gambar 1

Permainan Bentuk dan Warna pada Busy Book
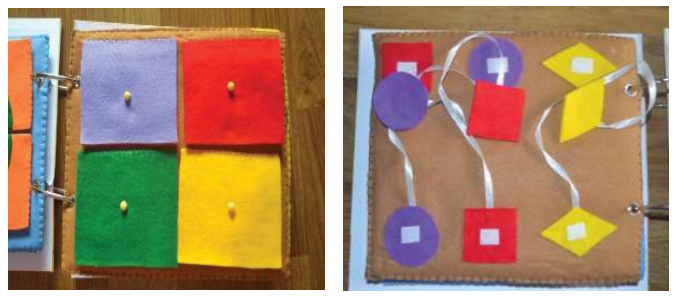

Sumber: Dokumen Peneliti 2020

\section{Gambar 2}

Mengenalkan Berbagai Jenis Binatang, Makanan, dan Tempat Tinggalnya

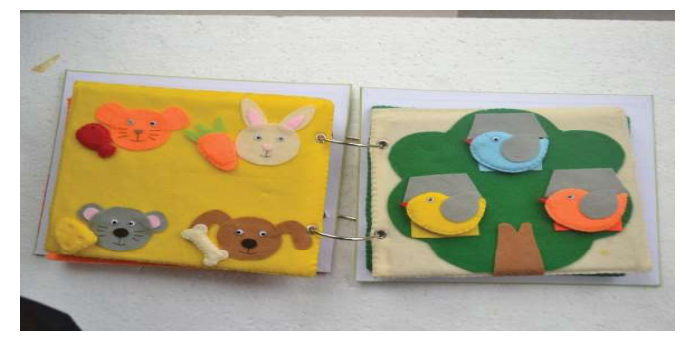

Sumber: Dokumen Peneliti Tahun 2020

Setiap anak pada dasarnya mengalami masa perkembangan fisik, psikomotorik, intelektual, dan sosial sesuai kemampuan dan pengalaman yang dimilikinya, meskipun kadar kemampuan yang dimilikinya juga beragam. Masa pengembangan kemampuan setiap anak tampak tidak selalu seiring atau bersamaan dengan usianya ada yang awal dan ada pula yang terlambat. Oleh sebab itu, perlu adanya media belajar yang dapat menstimulasi anak agar perkembangannya bisa lebih maksimal.

Salah satu kriteria atau prinsip media pembelajaran untuk anak media busy book memuat unsur media grafis. Pada media ini terdapat beberapa gambar. Wati (2016, pp. 36-38) mengatakan terdapat beberapa prinsip dan unsur pada pengembangan media grafis. yaitu sebagai berikut. Pertama, prinsip 
keterpaduan yang merupakan elemen-elemen yang saling terkait dan menyatu untuk menampilkan media yang menyeluruh dan dapat membantu pemahaman siswa. Kedua, prinsip penekanan yang merupakan penyajian media yang dibuat sesederhana mungkin agar dapat dijadikan pusat perhatian siswa. Ketiga, prinsip keseimbangan yang merupakan sebuah kesamarataan yang dicapai pada setiap unsur dalam tampilan media. Keempat, unsur bentuk yang merupakan unsur yang bertujuan untuk menarik perhatian siswa dengan bentuk media yang asing atau tidak biasa. Ketertarikan anak dapat ditingkatkan dengan mengatur tekstur dan ukurannya. Media busy book dilengkapi panduan bercerita untuk guru yang merupakan media hasil cetakan. Nilai estetika dalam busy book terletak pada tema, bentuk, dan warna (Gambar 1). Anak belajar dan bermain busy book untuk membangun etika dan estetika.

Kriteria fisik media cetak adalah sebagai berikut: fleksibilitas, yaitu media dapat diadaptasi dengan berbagai tujuan dan kondisi lingkungan; portabilitas, media mudah untuk dipindahkan dan tidak membutuhkan alat lain untuk membawanya; ramah bagi pengguna, media dirancang agar mudah digunakan dan tidak membutuhkan keahlian khusus untuk mengaturnya (Smaldino et al., 2011, p. 289).

Pada media grafis juga terdapat pengaturan warna, selain pengaturan gambar. Pemilihan warna untuk sebuah media pembelajaran hendaknya memperhatikan keharmonisan. Wati (2016, p. 39) mengatakan bahwa penggunaan warna dalam media hendaknya dapat mempertinggi tingkat realisme objek atau situasi yang digambarkan, menunjukkan persamaan dan perbedaan, serta menciptakan respon emosional tertentu. Pett dan Wilson (Smaldino et al., 2011, p. 83) menyebutkan beberapa saran dalam penggunaan warna pada sebuah media pembelajaran yaitu: konsisten dengan pilihan warna umum di seluruh material; menggunakan warna yang sangat jenuh untuk materil yang ditujukan untuk anak-anak kecil; memperhatikan makna-makna warna yang digunakan, misalnya merah dan kuning bermakna hangat, hijau dan biru bermakna sejuk; dan memperhatikan makna-makna para siswa dari berbagai latar belakang budaya berbeda letakkan pada warna.

Pada penggunaan media busy book juga memperhatikan unsur-unsur teks yang berbasis cetakan. Arsyad (2011, p. 87-88) menyebutkan bahwa unsur-unsur teks pada media adalah sebagai berikut: konsistensi dalam format dari halaman ke halaman; format yang merupakan tata letak teks yang disesuaikan dengan panjang atau pendeknya paragraf; organisasi yang merupakan penyusunan teks secara keseluruhan yang memudahkan sisa dalam memperoleh informasi; ukuran huruf yang merupakan pemilihan ukuran teks yang disesuaikan dengan siswa, pesan, dan lingkungannya; dan daya tarik yang berfungsi untuk memotivasi siswa untuk terus membaca.

Pengembangan media pembelajaran busy book ditujukan untuk menciptakan pembelajaran yang berpusat pada siswa. Oleh karena itu, perlu disertakan petunjuk penggunaan media. Smaldino et al. (2011, pp. 125-126) mengatakan bahwa dalam prosedur penggunaan media yang sistematis perlu memperhatikan beberapa kriteria yaitu: penggunaan bahasa yang sesuai, kualitas teknis, memiliki tingkat ketertarikan dan keterlibatan siswa, dan mudah digunakan.

Media edukasi adalah alat bantu yang berfungsi dalam menjelaskan sebagian ataupun keseluruhan program pembelajaran yang sulit dijelaskan secara verbal. Media edukasi bisa berupa materi pembelajaran, soal latihan, video, permainan dan lain lain. Pembuatan busy book dimaksudkan untuk mengeksplorasi kemampuan berpikir anak usia dini secara alamiah dengan bermain tanpa merasa sedang melakukan proses belajar. Tujuannya adalah untuk memunculkan rasa ingin tahu yang besar 
pada diri anak sehingga timbul kegiatan dan aktivitas belajar pada anak usia dini.

Anak usia dini lebih cenderung tertarik dengan buku-buku yang banyak gambar dibandingkan dengan buku-buku yang banyak teksnya. Mereka bisa menemukan informasi yang dapat menyenangkan hatinya pada buku tersebut. Di PAUD Yogyakarta dalam proses pembelajaran cenderung belum ada menggunakan busy book. Oleh karena itu, busy book perlu dibuat dan dapat digunakan sebagai salah satu media pembelajaran bagi anak usia dini untuk mempercepat kemampuan membacanya. Dengan adanya busy book yang disertai aktivitas permainan dapat memotivasi anak usia dini dalam belajar membaca dan belajar akan jauh lebih menyenangkan bagi anak.

Keterampilan motorik sangat penting di segala aspek kehidupan manusia. Bayangkan apabila seseorang kesulitan berjalan, berlari, atau beraktivitas di kehidupan sehari-hari. Bagi balita perkembangan motorik sangat penting bagi perkembangan intelektual dan keterampilan mereka. Perkembangan motorik pada anak diatur oleh prinsip-prinsip dasar tertentu.

\section{Gambar 3}

\section{Contoh Permainan Puzzle untuk Meningkatkan Kemampuan Motorik Anak}

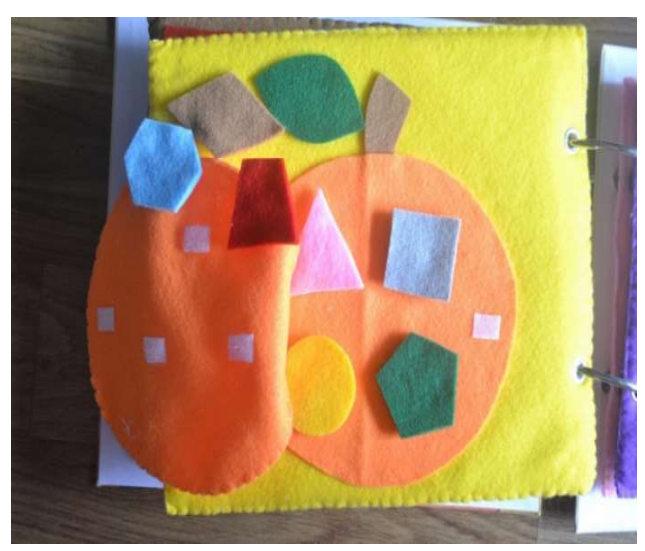

Sumber: Dokumen Peneliti 2020
Pertama, pematangan sistem motorik bergerak maju dari koordinasi otot-otot kasar (besar) menuju halus (kecil). Contohnya: sebagai bagian dari pembelajaran untuk meraih sebuah benda, lengan anak direntangkan untuk mengambil semua benda yang ada di hadapannya, lalu sebulan kemudian sebagai hasil dari perkembangan dan pengalamannya itu, koordinasi otototot besar anak dapat memuka jalan bagi penjangkauan spesifik sehingga ia bisa memilih dan memegang sesuatu objek/ bentuk tertentu yang diinginkannya.

Kedua, perkembangan motorik muncul dari kepala ke kaki (ekor). Proses ini disebut sebagai perkembangan cephalocaudal (cephalocaudal development). Saat lahir kepala anak adalah bagian tubuh yang paling berkembang, namun setelah itu bagian lain dari tubuhnya juga tidak kalah pentingnya. Sebagai contoh anak mulai berusaha menegakan kepalanya sebelum bisa duduk, kemudian merangkak, dan duduk dulu sebelum bisa berjalan.

Ketiga, perkembangan motorik bergerak dari proksimal (yaitu garis tengah atau pusat tubuh) menuju distal (yaitu anggota tubuh) dikenal dengan perkembangan proksimodistal (proximodistal development). Contohnya anak mampu mengontrol gerakan-gerakan lengannya sebelum ia dapat mengontrol gerakan-gerakan jarinya.

Pada permainan busy book ini dirancang untuk dapat dibuka, ditempel, digeser, dan buka tutup. Pada aktivitas lepas, tempel, geser ini membangun imajinasi anak akan pola, bentuk, warna dan gerakan objek yang sesuai dan rasional. Anak akan belajar hatihati untuk mengendalikan motorik halusnya. Dalam proses itu anak bermain dan belajar ketepatan bentuk, warna, kecermatan, dan dilatih tanggung jawab sebagai bentuk belajar nilai edukasi.

Perkembangan bahasa anak diperoleh karena faktor hereditas. Pertama, manusia memiliki sistem dan saluran pernapasan 
yang memungkinkan komunikasi vocal dilakukan secara efisien. Kedua, otak manusia memungkinkan untuk berbahasa. Otak kiri adalah pusat bagi ujaran dan analisis fonetik, merpakan pusat bahasa otak manusia. Otak kanan juga memiliki peran dalam pemahaman akan intonasi ujaran yang memampukan kita memilah kalimat-kalimat pernyataan, perintah, dan bertanya.

Beberapa teoretisi yakin bahwa secara bawaan manusia sejak lahir sudah dilengkapi dengan kemampuan untuk memproduksi bahasa. Namun, kapasitas produksi ujaran dan aspek-aspek terkait penguasaan berbahasa berkembang sesuai dengan tahapan dan jadwal yang sudah tertanam secara biologis pada manusia. Montessori menjelaskan bahwa terdapat dua jenis tahapan. Pertama, dimulai sejak lahir hingga usia 3 tahun. Selama perioe ini anak tanpa sadar menyerap bahasa dari lingkungannya. Kedua, dimulai dari usia 3 tahun sampai usia 8 tahun. Di periode ini, anak menjadi partisipan aktif di dalam perkembangan berbahasa mereka dan belajar cara menggunakan kekuatan komunikasi mereka.

Faktor lain yang mempengaruhi perkembangan berbahasa pada anak yaitu faktor lingkungan, selain faktor hereditas. Isi bahasa sintaksis, gramatika, dan kosakata diperoleh dari lingkungan yang mengandung keterlibatan orantua dan orang lain sebagai model berbahasa. Perkembangan ini bergantun pada percakapan anak dan orang dewasa, dan antar anak dengan anak lainnya. Dengan kata lain, perkembangan berbahasa yang optimal bergantung pada interaksi dengan model-model berbahasa yang terbaik. Oleh sebab itu, proses biologis kemungkinan sama untuk semua anak, namun isi bahasa bisa berbeda sesuai faktorfaktor lingkungannya. Anak-anak di rumah yang terbatas komunikasi bahasanya tidak akan belajar bahasa sebaik anak yang diasuh di lingkungan yang kaya berbahasanya.

Salah satu tujuan penggunaan busy book pada anak usia dini adalah untuk meningkatkan kemampuan komunikasi dan berbahasa anak. Manfaat yang dapat diperoleh dengan belajar menggunakan busy book adalah mengurangi rasa frustrasi anak dan orangtua, menguatkan ikatan anak dan orangtua, memudahkan pembelajaran bicara, menstimulasi perkembangan intelektual, meningkatkan rasa percaya diri anak, dan meningkatkan perbendaharaan kosakata, gramatika, dan sintaksis anak

Saat menggunakan busy book untuk bermain sekaligus sebagai media pembelajaran, orangtua atau guru dituntut menjadi komunikator yang lebih terampil dalam penggunaan gesture tubuh, ekspresi wajah, intonasi suara, penunjukan dan penjangkauan agar intruksi atau maksud dari pembelajaran dapat di tangkap dan dipahami anak. Misalnya guru atau orang tua memberikan intruksi "Ayo gabungkan bagian ini" atau "Di mana letak bagian ini?". Setelah memberikan intruksi guru atau orangtua bisa mengamati sikap responsif anak untuk membaca tanda dan sinyal, dan memahami bahasa. Semakin banyak bahasa atau kosa kata dan simbol yang ditampilkan guru atau orantua maka semakin berkembang pula kemampuan bahasa verbal dan visual anak.

Tujuan yang selanjutnya hendak dicapai adalah kemampuan untuk komunikasi dari bahasa tanda dan suara menuju penggunaan kata-kata tunggal. Anak-anak berbicara tentang manusia, bapak, ibu, kakak adik, anak, yaitu hal-hal yang merujuk pada dirinya sendiri melalui media busy book guru atau orangtua dapat memperkenalkan sosok tersebut pada anak. Kalimat-kalimat satu kata yang digunakan anak utamanya bersifat perujukan (digunakan untuk merujuk objek, contohnya: boneka), namun bisa juga menjadi sebuah ekspresi yaitu mengkomunikasikan keinginan pribadi atau tingkat intersksi sosial. Bahasa yang digunakan anak mencerminkan gaya bahasa orangtua atau orang yang dikenalnya. 
Dengan kata lain, guru atau orangtua maupun orang terdekatnya mempengaruhi cara anak berbicara. Dengan adanya busy book, membantu orangtua untuk mengelola bahasa yang akan ditunjukan pada anak. Belajar dan bermain busy book untuk membangun kemampuan berbahasa, berkomunikasi, berinteraksi melalui berimajinasi dengan permainan tersebut.

\section{Gambar 4}

Bentuk Busy Book dengan Kegiatan Mengenalkan Alat Komunikasi dan Informasi

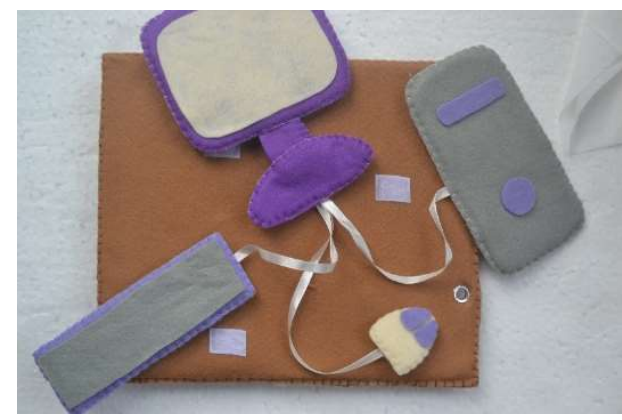

Sumber: Dokumen Peneliti, 2020

\section{SIMPULAN}

Beberapa kelebihan media busy book yaitu dapat meningkatkan kinerja otot untuk melakukan gerakan, melatih kemampuan kognitif, membantu dalam memecahkan masalah, melatih rasa tanggungjawab, melatih koordinasi mata dan tangan, ketepatan dalam memegang benda dan meletakkan sesuatu sesuai tempatnya, dan dapat melatih anak dalam menulis dan makan dengan baik. Kegiatan peningkatan motorik halus melalui media busy book dapat meningkatkan kemampuan bina diri anak sehingga dapat bermanfaat bagi anak di kemudian hari, agar anak mampu melakukan kegiatan sehari-hari secara mandiri.

Busy book merupakan media permainan untuk belajar melalui bermain bagi anak dan seni anak adalah sesuatu yang dihasilkan dari permainan. Bermain bagi anak merupakan wahana belajar untuk mengeksplorasi lingkungan yang dapat mengembangkan kemampuan fisik, kognitif, dan sosialemosional anak. Di samping itu, bermain busy book mengembangkan individu agar memiliki kebiasaan-kebiasaan baik, seperti berkomunikasi, berbagi peran, belajar disiplin, belajar ketelitian, kesabaran, kecermatan dengan bentuk dan warna, berani mengambil keputusan dan belajar bertanggung jawab untuk melepas, menempel, dan menggerakan seperti bentuk semula. Bermain dapat mengembangkan kemampuan berimajinasi, berapresiasi dan berkreasi pada diri anak sehingga nilai estetika dan etika dapat terbentuk secara optimal.

\section{DAFTAR PUSTAKA}

Arsyad, A. (2011). Media pembelajaran. PT. Raja Grafindo Persada.

Bogdan, R., \& Taylor, S. J. (1993). Kualitatif dasar-dasar penelitian. Usaha Nasional

Moleong, L. J. (1999). Metodologi penelitian kualtatif. Rosdakarya.

Smaldino, S. E., Lowther, D. L., \& Russell, J. D. (2011). Teknologi pembelajaran dan media untuk belajar. (Terj.: Arif Rahman). Kencana Prenada Media Grup.

Sukmadinata, N. S. (2005). Metode penelitian pendidikan. Remaja Rosdakarya.

Suyanto, S. (2005). Dasar-dasar pendidikan anak usia dini. Hikayat.

Wati, E. R. (2016). Ragam media pembelajaran. Kata Pena. 